\title{
From Fordism to Post-Fordism: Representation of Work in the Films about Nazi Concentration Camps
}

\author{
By Ewa Mazierska
}

Fall 2013 Issue of KINEMA

\section{FROM FORDISM TO POST-FORDISM: REPRESENTATION OF WORK IN THE FILMS ABOUT NAZI CONCENTRATION CAMPS}

Nazi concentration camps in cinema, as well as in other media, tend to be represented as an aberration from the human norm. Watching films about the camps (the mainstay of the Holocaust film), we get the impression that there is a clear division between life in a camp and normal life. The inclusion of walls and barbed wire, marking the boundary between the prisoners' world and that of free people, as well as between camp and non-camp stages of the characters' lives confirm this impression. I also regard camps as extraordinary. This extraordinariness has a double meaning. In some aspects Nazi camps deviated qualitatively from ordinary institutions and everyday practices. In others, they were different in a sense of intensifying certain aspects of practices tested in other historical circumstances or even regarded as normal and necessary for society to function, even if unfortunate. I argue that the camp's approach to work was extraordinary in the second sense.

The purpose of this essay is to assess how representations of camp work reflect the views on work pertaining to times and places when these films were made. I will thus treat the Holocaust films not only as films about the past, but also about the present. It should be mentioned that such an approach, which is almost standard in the case of films on other historical subjects, is rarely applied in discussions of Holocaust cinema. When the Holocaust is represented, its principal referent or hypotext, to use the term from adaptation studies (Stam 2000), is the Holocaust itself, rather than, for example, the book adapted for the screen or the cultural context of its production (Mazierska 2007: 156). The question at the centre of the discussion is how truthful the representation is; examining the context merely serves to explain any possible inaccuracies. ${ }^{(1)}$

As it will be impossible to include in this essay all camp films or even a representative sample (films on this topic, even if we take into account only feature films, by now can be counted in hundreds), I will limit myself to three distinct examples: Andrzej Munk's Pasaerka (Passenger, 1963), Leszek Wosiewicz's Kornblumenblau (1989), and Steven Spielberg's Schindler's List (1993), inasmuch as they lend themselves to the aforementioned treatment, providing insights into the realities of 'civilian' work and, at the same time, illuminating aspects of working and living in the camps. I argue that Passenger pertains to Fordism and socialism, marked by large-scare industrial production, rigid division of labour and hostile attitude to capitalism. Kornblumenblau and Schindler's List reflect on post-Fordism and neoliberalism, characterised by domination of service work over industrial production, flexible working patterns, and the widespread assumption that there is no viable alternative to capitalism (on explaining these terms see Harvey 1990; 2005; Amin 1994; Virno 2004).

Before moving to films, however, I would like to offer a summary of work in the camps as represented in other types of narratives, most importantly, historical sources. I privilege sources concerning Auschwitz and specifically Auschwitz III, also known as Buna-Monowitz, which was a labour camp. ${ }^{(2)}$ This is because Auschwitz, understood as a network of concentration and extermination camps, is regarded as 'the mother of all camps', the apogee of Nazi treatment of their enemies and a model emulated in other camps. Moreover, there exists more data about this camp than others and two of three films I discuss are set there. I use historical sources not to establish whether specific films adhere to allegedly more reliable material about the camps, but rather to demonstrate that the facts about the work in Auschwitz are open to varied interpretations.

\section{Work, death and survival}

In Auschwitz, the daily schedule was fixed. A succession of orders by the camp commandants introduced changes in the hours that the prisoners worked, the length of roll-calls, work on Sundays, and so on. However, throughout, the prisoners spent ten or more hours at work, with the rest of their time being filled (until the end of 1942) with long roll-call assemblies, waiting for meals and free places in the latrine or washroom, 
removing dirt and insects from their clothing, and disinfection. The prisoners were roused at 4:30 in the morning in summer and an hour later in winter. Faint with lack of sleep, dulled by the stuffiness that prevailed in their quarters or stiff from the cold, they were chased outside at the sound of a gong by their block supervisors, assistant supervisors and room wardens. These functionaries usually stood outside the block doors and urged the prisoners to hurry by hitting them with sticks. In the time between the gong and the morning roll-call assembly, the prisoners had to wash, visit the latrines, and above all put their quarters in perfect order.

This description, although demonstrating that the life of Auschwitz's prisoners was very hard, by no means suggests it was unique. It uncannily recollects descriptions of work of African slaves shipped to American plantations in the eighteenth century (Grant 1968) and workers in English factories in the nineteenth century, provided by, among others, Marx, Engels and Lafargue (especially Marx 1965: 231-302; Engels 2009; Lafargue 2002). The working day in capitalist factories was even longer than in Auschwitz and those who worked there were treated callously by their superiors. It was also not infrequent that factory workers died of overwork combined with malnutrition. Paul Lafargue quotes an anonymous pamphlet, which in 1770 appeared in London under the title 'An Essay on Trade and Commerce', which 'proposed to imprison the poor in ideal "work-houses", which should become "houses of terror, where they should work fourteen hours a day in such fashion that when meal time was deducted there should remain twelve hours of work full and complete" " (Lafargue 2002: 15). Douglas Grant mentions the practice of 'mutilating one or two slaves on their way to their destination as a warning to the others slaves' (Grant 1968: 75).

Furthermore, in a factory system, as in the camp, promotions were rare and most workers experienced little improvement during their working life. In both systems, choosing not to work had very severe consequences. In England those refusing were forbidden to roam the country and were put into poorhouses where conditions were even harsher than in factories (Pollard 1963). Those caught avoiding work in the camp risked a severe beating or even death. Slave system, 'ordinary' capitalism and the 'camp system' relied on the existence of a surplus population vulnerable for exploitation. But there were also important differences between working in a factory in Manchester in the nineteenth century and working in Auschwitz. One difference resulted from the overall ideology of Nazism. Although it embraced many elements of classical capitalism, such as colonialism, it also has anti-capitalist connotation, expressed by its emphasis on a strong state, a need to lift people out of poverty and moralistic condemnation of certain peculiarities of the character of capitalists, such as greed and rootlessness. These peculiarities were (dis)located to one section of the German population, the Jews, who in this way were sentenced to extinction.

These ideological differences affected the role of the surplus population and the purpose of the respective systems. In the factory system the surplus population constituted a cheap army of available workers. This army was needed to keep the wages low and ensure the domination of capital. The capital class had no reason to destroy or even diminish this army. By contrast, destruction of the surplus population was the ultimate goal of Auschwitz and work was a means to fulfil this objective. The work was so hard that it killed a statistical Auschwitz prisoner much sooner than the factory worker. The camp's commandants openly told the prisoners that they will survive there on average only three months. In Auschwitz workers were also used to exterminate each other, by building gas chambers and crematoria, as well as administering the poison gas. As the war ended before this goal was achieved, it is impossible to predict what would have happened afterwards, namely whether the Nazi system would feed on a new wave of surplus population or wind down after completing its programme of exterminating the Jews, Roma, Russians, Poles, homosexuals, becoming 'normal' capitalism.

The difference in purpose hugely affected the organisation and operation of the respective institutions. Factory workers retained some personal freedom, even if their real freedom was circumvented by economic circumstances and they were paid with money which in theory increased their freedom, even transformed them into small capitalists. Auschwitz prisoners were literally slaves and could not leave the confines of the camp without permission on sanction of death. They were not paid for their work with money, only with meagre rations of food and, at best with a surrogate currency, camp money, which could be used to buy food and services only within the boundary of the camp.

The capitalists did not spare money to invest in the factories, if they expected that it will increase their 
profit. Machinery was thus used to replace human labour and there was a drive to specialisation of labour, to increase each worker's productivity. As profit was not the main objective of the camps, but self-sufficiency or rather self-annihilation, as little was invested in them as possible. It led to using archaic technologies, manual labour where machines and tools would normally be used and wasting skills, because they were not needed in the camp or because those who possessed them, most importantly Jews, were deemed unworthy to be given certain occupations. Due to the need for self-sufficiency, as well as security, a high proportion of inmates (typically about 30\%) were always employed in expanding and maintaining the camp. These traits rendered the camps very archaic - as if they signified a return to the time of building pyramids. This analogy is particularly pertinent, as concentration camps (although not Auschwitz) were usually built near the places rich in building materials, so that the prisoners could work in quarries, brickyards and gravel pits, to produce material to be used in the erection of the grand public edifices and other state and party buildings that Hitler intended as his lasting contribution to the Thousand-Year Reich. ${ }^{(3)}$ Due to the aforementioned reasons, the productivity of the camp workers was lower than that of civilian workers. According to records kept by industrial plants (the camps kept no such records), prisoners were on average $40 \%$ to $60 \%$ as productive as civilian workers, despite attempts to increase their productivity by prolonging their working day and making them work in shifts.

However, the situation of Auschwitz inmates underwent significant changes during its history, as in other Nazi camps. While in the first years of its existence, work was predominantly an instrument of punishment and harassment of the prisoners, later its main purpose was to assist Germany's war effort. Hence, while initially the workers were confined to the camp, increasingly they were used for work outside it, first in statemonopoly and then in private firms, to make up for shortages of civilian workers, rendered acute under war conditions. Workers were most needed for the extraction of raw materials and producing chemical substances to replace them. A large number of them were sent to mines, ammunition factories and chemical factories. IG Farbenindustrie (aka as IG Farben) was the first civilian company to use them, becoming a symbol of exploitation of the camp system by German industry (Piper 2002: 21).

Although prisoners were doing for free the work civilian workers did for money, and ample literature is devoted to the abuses the prisoners suffered by civilian overseers and co-workers, one also observes that the status of prisoners improved when they, literally and metaphorically, left the camp. This was caused not so much by the outside firms treating the prisoners better than the camp authorities, but by the latter experiencing a shortage of workers and intervening in such situations. In an order circulated to the Lagerführers of all the sub-camps on July 14 1944, the commandant of Auschwitz III stressed that 'it is inadmissible for foremen to keep skilled prisoner labourers at work for the night after they have already put in a day's work' (ibid.: 314). As time went on, there were more and more problems associated with the exhaustion of the camps' human resources, especially among skilled workers.

The SS authorities had to introduce new means of making prison labour more productive, like occupational training, matching employment to qualifications, improving living conditions and providing certain incentives for work. However, within the camp these measures brought very limited success, not least because the rapid turnover of prisoners who generally died within a short period of time made occupational training a poor investment. The gradual increase in the role that prisoner labour played in armaments production meant that, in the last years of the war, skilled workers began to be treated better than the mass of unskilled prisoners. There had already been signs of such a tendency earlier, often at the insistence of industrial firms. The skilled workers usually worked indoors, got more food and had access to other scarce goods, such as toiletries.

Thus it is not a surprise that among the survivors we find a high proportion of skilled people: engineers, electricians, artists. Examples include an Italian engineer and later writer Primo Levi or Polish sculptor Xawery Dunikowski. Another way to survive and even have a bearable life in the camp was to get the position of an overseer. Much has been written about the comfortable lives of Auschwitz's kapos, such as that of Bruno Brodniewicz and Ernst Krankemann, who had the authority to kill fellow prisoners and frequently took advantage of this right. The positions of overseer were given largely to those prisoners without moral scruples, often with psychotic, sadistic character (ibid.: 116-17).

For those who did not have any special skills and were condemned to manual labour, prospects were especially 
bad. But even the prospects of such prisoners varied. Much depended on each person's health and strength as well as luck. For example, those under the control of the cruellest kapos fared worse than those exposed to less deranged individuals. The key to survival, as we learn from the memoirs of ex-prisoners, was to avoid work, yet pretend to work or work only when observed. For example, Stanislaw Grzesiuk, author of the popular Polish book, Pi lat kacetu (Five Years in the Camp, 2010) who, true to its title, spent over five years in three different concentration camps (Dachau, Mauthausen and Gusen), writes on the first page: 'The basis of the life in the camp was avoiding work and focusing on arranging food. Those who worked hard, fulfilling all the orders of the camp's overseers, would certainly end up in the crematorium' (Grzesiuk 2010: 7-8). It is also worth adding that in the museum, organised on the site of the Majdanek concentration camp one can see a sculpture, designed by one of the prisoners, showing a tortoise, with the inscription 'Work slow'.

\section{Passenger: camp as an arena of class struggle}

Passenger is regarded as a breakthrough in the representation of camp life and even as the ultimate 'camp film' in Poland and the world at large. It was argued that, unlike the highly propagandist works of the previous socialist realistic period, in particular Ostatni etap (The Last Stage, 1947) by Wanda Jakubowska, Munk, inspired by the stories of Tadeusz Borowski, avoids strident proselytising and concentrates on documenting typical days and nights in the camp (Nurczyska- Fidelska 1982: 121-65). This means showing prisoners at work, barely included in Jakubowska's classic. For example, we see a group of men harnessed to a huge roller, which is a likely reference to the practices of the sadistic kapo Krankemann, mentioned earlier, women working in a detail sorting the belongings of people brought to Auschwitz (so called Kanada) and men playing in a small orchestra. Yet, there is no documenting without transmitting a specific ideology and this is also the case here. This ideology can be largely deduced from the time and place the film was made: Poland under communist rule and Munk's own career. During this period in Poland and in the socialist world at large, the factory, organised along the Fordist lines, remained the privileged site of creation of the country's wealth. There was a tendency towards excess, to 'Magnitogorsk mentality' or 'investment fetishism', which manifested itself, among other things, in big enterprises, often employing thousands of people (Cohen 1985; Bunce 1999: 24). Although Munk was expelled from the Polish communist party in 1952 and many of his films were interpreted as critical of communism, most importantly Czowiek na torze (Man on the Tracks, 1957), this criticism was always from a left-wing position. Munk never rejected communism, only argued for its improved version, in which a worker will have more political power and his/her alienation, if not totally abolished, will be eased.

In Passenger Munk suggests that the concentration camp is an extreme case of the capitalist system, with its various features, such as industrialism and colonialism intensified. Here, industrial work dominates over service, which will be privileged in the subsequent camp films. This fact is reflected in the factory mise-enscène; if we remove from the scene the people in striped clothing, we get a picture no different from those common in many 1960s Western and Eastern 'factory' films, such as Il deserto rosso (Red Desert, 1964) by Michelangelo Antonioni or ovek nije tica (Man Is not a Bird, 1965) by Dušan Makavejev, due to prevalence of factories with tall chimneys shot in long takes.

However, the 'raw' material processed in the Auschwitz factories are human bodies sent to the gas chambers, which can be seen as a literalisation of Marx's frequent metaphors of capitalism feeding on workers' bodies, like a vampire who cannot be ever satisfied (see especially Marx 1965: 256; Neocleous 2003). But, of course, the literalisation of Marx's metaphor, offered by Munk, suggests that in Auschwitz reality exceeded what the author of the metaphor envisaged. We also see the immense amount of goods looted by the Nazis during their rapid colonising pursuits, which are sorted in Kanada. Many of them, such as ornamental vases, look oriental, evoking the colonial past of countries such as England or Spain, as well as of Germany's dream to measure up to them. Again, they can be viewed in the context of condemnation of colonisation/imperialism as the highest stage of capitalism, represented in the works of Marx, Rosa Luxemburg and Lenin. Munk shows that the speed of Germany's colonisation exceeds its ability to use its fruits rationally.

A large proportion of the goods brought by Jews and described by Liza, the overseer of the Kommando, working in Kanada, as the 'property of the Reich' is thrown away. Likewise, there are too many prisoners to engage them in fruitful work, therefore they are made to run in circles, push heavy objects up and down or provide entertainment for the Nazis. This treatment confirms the rule, identified by Marx and put eloquently by Zygmunt Bauman, that for the capitalist it is better if the worker dies from unproductive work or hunger 
than if he rests and eats what the capitalist throws out (Bauman 2005: 118). The rationale behind this work ethic is that the labour force must be continuously occupied and threatened; only such treatment guarantees that it will remain placid and ensure the survival of the system.

Munk's Auschwitz, conforming to the Fordist scheme, is a stable world, in which both the prisoners and their bosses (SS-men and women) remain in the same place for a long time. We do not hear about any promotions during the film, neither about prisoners or SS-people moving commandos. The division of labour in the camp is rigid: the supervisors are all German; the labourers are all non-German, mostly Polish. It is also rigid in the sense that labour time (although torturously prolonged) and spaces of labour are clearly separated from periods and places of rest.

The camp work ethic is rejected by the prisoners (it cannot be accepted voluntarily, as normal men do not agree to be slaves), but the Nazis sincerely believe that it benefits not only them, but humanity at large. Liza, in particular, is convinced that she works for a higher purpose - a better world, envisaged by Hitler, and her sacrifice is much greater than that of the ignorant prisoners, unable to see the 'big picture', created by her master. This belief furnishes Liza with some dignity, helped by casting in this role Aleksandra lska, one of the greatest Polish actresses of the postwar period. Contrary to the stereotype of a Nazi, Liza is able to treat the prisoners, or at least one prisoner, Marta, as a subject, not an object, even somebody equal to herself. To gain Marta's heart, Liza looks after her better than after other prisoners, offering her some scarce goods and less strenuous work. Marta, on the other hand, uses her position to engage in an anti-Nazi conspiracy and with fellow workers manages to rescue a Jewish child. For her defiant behaviour Liza punishes Marta, sending her to a certain death. Marta, however, survives and after the war, by meeting Liza by chance on a liner sailing to South America, forces the ex SS-woman to reveal what she did during the war, albeit only in an internal monologue. Liza's likely comfortable life in West Germany and her travel to South America can be viewed as a testimony to the fact that the 'Nazi capitalism' survived the war and became reborn in a 'softer mutation'. Yet, it lost its self-confidence, as proved by the fact that Liza keeps changing her memories about her time in the camp. The interaction between Liza and Marta, both during and after the war is thus presented as a struggle not so much for economic domination (this is ensured by erecting the camp), but for moral victory. Their fight can be regarded as a dramatisation of a larger struggle between the capital and the proletariat, led by its avant-garde, namely workers with the most developed class consciousness. If we regard the concentration camp as an extreme case of work relations in capitalism, then the lesson is that the workers should not give in to the demands of capitalists, as their ultimate goal is exploitation and then destruction. Only through resistance to oppression, through class struggle, can the proletariat achieve any improvement of its position and, ultimately, a victory.

\section{Kornblumenblau: camp as a post-Fordist universe}

Kornblumenblau was made in 1988 and had its premiere in 1989: the symbolic year of the fall of communism in Poland and its entering capitalism in its post-Fordist and neoliberal variation. This passage can be seen as a move from hard to a softer form of exploitation, in which the state withdraws from its function of rewarding and punishing people for their work; this is left to economic mechanisms. Under a neoliberal regime the control of capital is often diffuse and remote. The owners of (off-shore) factories live far away and many companies do not have single owners but belong to shareholders. For these reasons and the overall fluidity and instability of neoliberal capital, its embrace of never-ending transformation and crisis, the neoliberal capitalist is not expected to be loyal to his factory, which means that workers' circumstances are also less stable than they were under Fordist rules. They expect to be in constant movement: horizontally, moving from city to city and country to country in search of employment, often in new branches and vertically, being prepared for unexpected promotions and demotions. Under the neoliberal regime, the demands are usually passed onto workers, not directly by their superiors but are conveyed by seemingly impersonal rules, communicated to them by computers.

Furthermore, the frequently self-employed workers are paid according to the fulfilment of a specific tasks rather than according to hours of work, which leads to working more rather than less than in a Fordist factory and blurring the division between work and non-work. One psychological strategy of dealing with the high demands of work is to convince oneself that work is what one's life is all about - there is no life outside work. Inevitably, the less time is devoted to activities not related to work, the more difficult it is to imagine a different life. Under this system the workers become the agents of their own oppression. 
Not surprisingly, this period saw a proliferation of studies drawing on Michel Foucault's analysis of power, and especially concepts such as 'governmentality' and 'technologies of the self' (Foucault 1988; 1991; Hindes 1996: 96-136), which emphasise the person's internalisation of demands by a specific authority - not by making the personal political, but the political personal (Cruikshank 1996). Although Foucault introduced these terms to describe the period of modernity at large, they seem particularly fitting to capture the times when people need no rods, commands barked out by their supervisors or even alarm clocks to do what is expected of them, although their behaviour accelerates the vicious circle of exploitation and oppression. I see Wosiewicz's film as a premonition of this change.

The film begins with a montage of archival footage which showed Poland standing for Europe at large before the Second World War, edited together with scenes from the life of the family of a bank clerk, in a way that is difficult to detect which fragment belongs to the documentary and which to fiction. The purpose of this introduction to the main part of the film is to explain the situation of the film's protagonist, Tadeusz (Tadek), born during the First World War. According to the decision of his parents, he gets a double education: that of a musician and engineer, to ease his way into different situations in life. Such an approach, although ostensibly pertaining to times when nobody had heard of 'Fordism', much less 'post-Fordism', can be seen as revealing a post-Fordist mindset, expecting the ever-changing circumstances to which one can prepare one's offspring by helping them to develop multiple skills. Wosiewicz intimates that such an attitude reflects a turbulent Polish history, which forced Poles to prepare themselves to constant changes, including wars fought by foreign empires on Polish soil. The life strategy of adjustment, which Tadek's parents want to instil in their son, contravenes the dominant, Romantic paradigm of Polish history, which emphasises Polish efforts to shape their own fate by instigating uprisings and taking sides in wars rather than merely going with the tide of events.

In the main part of the film Tadek is sent to the concentration camp as punishment for participating in an anti-Nazi conspiracy. However, the heroic pre-camp part of his life is omitted and he himself never ponders on it. Once in the camp, Tadek's entire existence is in the present. He seems to have neither memories nor plans for the future, unlike the women from Jakubowska's The Last Stage and Munk's Passenger who get strength to survive the camp from their hope to be able to tell the truth about this hellish place once they return to normality. The focus on the present means privileging the needs of one's body over those of the mind, which, at the same time, mirrors the way prisoners are treated by the authorities in the camp: as bodies to be disciplined, used and disposed of when they are no longer useful. An example is an 'initiation rite' to the camp consisting of shaving men's pubic hair, a nail pricking their bottom after their photographs are taken, as a way to communicate that the task is completed, giving them striped uniforms and requiring them to introduce themselves by their numbers rather than names.

All of these and similar practices are meant to obliterate differences between the prisoners, render them interchangeable and anonymous. We are also continuously exposed to naked male bodies and the camera focuses on bodily functions: eating, defecating, vomiting, copulating, in other words, on the 'bare', physical life of the inmates. Fittingly, in the first part of the film, when the regime of human degradation is particularly severe, the camera is situated near the floor, as if not to miss the lower parts of the inmates' bodies. Wosiewicz also underscores the primacy of body in the camp by showing that the state of a prisoner's body determines the way he is treated. Those with weak bodies are deemed worthless and are disposed of by being gassed.

Yet, in this cruel and impoverished world one can still progress or even make a career. Tadek's story is the narrative of his climbing the Auschwitz ladder. It starts, literally, at the bottom of the human pile and in a horizontal position. Tadek's first 'job' is to take part in a medical experiment of testing an anti-typhus vaccine. Many inmates die as a result of being injected with typhus germs but Tadek survives and his life improves. This incident provides a pattern: Tadek enters a situation which proves deadly for many other prisoners, but he manages to survive, thanks to a mixture of good luck and versatile skills. Each survival leads to an improvement of his work conditions and overall situation. After surviving the typhus experiment he is moved to heavy manual work but thanks to being able to play the accordion is chosen by a German kapo to entertain him by playing the titular German song Kornblumenblau. Although in due course the kapo leaves the camp to fight on the Eastern front, prior to his departure he makes sure Tadek is taken care of by another overseer and lands the privileged job of peeling potatoes for the Germans. 
The next stage is getting work as a waiter and a piano player, serving and entertaining SS-men. Tadek even gets 'camp money' and is able to venture beyond the main camp and to use the sexual services of female prisoners dwelling there. At this stage he lives in a bloc for artists which looks more like an army barrack with proper beds covered with bed linen. Each step, however, brings not only advantages, but also unpleasant surprises. As a waiter he slips and breaks the plates he is carrying and during his session in a brothel is raped by two women rather than getting pleasure from sex. The worst moment comes when he is punished for not informing his superiors of the escape of some prisoners working in the kitchen and ends up in a hunger bunker. He is meant to be executed but, again, survives thanks to a stroke of good luck.

Tadek's progression is depicted against the wide panorama of camp life. Wosiewicz oscillates between closeups and long takes, to allow us to see the connections between camp (macro)politics and (macro)economy and the experience of individuals. Thanks to his focus on an individual who remains in the camp for a long time (unlike the average three months the Auschwiz prisoners survived) and his 'curious camera' moving around the camp, Wosiewicz probably holds a record in showing the variety of possible occupations of camp prisoners. We see various types of productive work, such as on a construction site, in service, such as in the kitchen or in a restaurant, in transport, professional work, in an accountancy office, finally semi-artistic and artistic work, as a photographer and painter, performing in a small orchestra and playing solo on various instruments. Much of the work is a form of torture, as it is done under duress, in haste, without paying attention to the quality of the final product. However, on occasions prisoners enjoy their work.

This happens when they are promoted, for example from work on the construction site to the kitchen. On this occasion work is described as 'pure heaven'. Working makes them happy also when they transcend their 'job description' and do something for their own pleasure, like when Tadeusz starts to play Chopin at a party for the Nazis. They also enjoy their work when they manage to cheat their superiors: steal food from the restaurant or spit to the soup served to the Nazis. Most importantly, however, Wosiewicz shows pleasure yielded to prisoners by holding positions of power: giving orders to fellow prisoners and managing their work. This almost absolute power renders kapos sadistic and vulgar, as sadistic and vulgar as the Nazis were portrayed in the earlier 'camp films'. We see, for example, a prisoner with a Star of David on striped suit, ecstatically riding a cart, pulled by a group of fellow prisoners, who are driven by him with cries and a whip.

Wosiewicz's camp looks practically like a self-governing world, with the inmates ensuring that it works to their invisible masters' satisfaction. Although we see walls with barbed wire at the beginning of the film, most of the time it looks like an 'open' city, with normal streets, whose inhabitants clear snow in winter and decide themselves how to organise their lives. Such a representation, coupled with the epigraph from Montaigne pronouncing that one always plays roles in one's life, encourages us to see in Wosiewicz's film not only a description of a specific, camp experience, but a metaphor of living under any circumstances, because under every circumstances one has to perform and conform.

The fact that the conformity is achieved mostly by what Foucault describes as technologies of the self and the enforcement by what can be described as the camp's lower and middle-management, shows a special affinity between 'Wosiewicz'c camp' and neoliberal, post-Fordist world. Another point of correspondence between these two systems is the lack of any political activity on the part of the prisoners or, indeed, the camp's leadership. Nobody talks here either about communism, Nazism or patriotism. Nobody mentions Hitler, Stalin or any other leader. Politics is all but forgotten amongst the camp's routines. However, Wosiewicz shows that the real goal of technologies of the self and self-government of prisoners is not empowerment and freedom or even easing their misery, but enforcing bondage. This is suggested most clearly in an episode showing the prisoners building what looks like a crematorium, possibly inspired by Jerzy Grotowski's staging of Stanisaw Wyspiaski's play Akropolis and their work in Sonderkommando, killing people in gas chambers.

Kornblumenblau, like Passenger, does not finish during the time of the camp, but shows what happens when the camp is demolished. Yet, it differs poignantly in its diagnosis of post-camp reality. Unlike in Passenger, where the end of the war and the accidental meeting between Marta and Liza forces Liza to assess her life, defend herself and admit her guilt, Kornblumenblau plays down the division between camp and post-camp reality. For some prisoners the bombardment of the camp equals a tragedy marked by the loss of their beloved masters. Tadek regains his freedom but only to enter a new circle of oppression. This is suggested by him 
learning to play another foreign song, Kalinka, for the new liberators, but in fact oppressors, the Soviets, on a train, which does not go through open country, towards freedom, but slows down and enters a "depo" or a tunnel, bringing association with the trains arriving in Auschwitz. To paraphrase the famous words by Fredric Jameson who said that it is easier to imagine the end of the world than the end of capitalism, we can say that it is easier to imagine the end of the world than the end of the camp.

\section{The magnitude of ideology-free capitalism in Schindler's List}

Schindler's List is an American film and, at the same time, the most successful film about the Holocaust ever produced. It was made shortly after Bill Clinton became the American President. Despite being a Democrat, he continued the neoliberal politics of his Republican predecessors, Ronald Reagan and George Bush, pronouncing 'free capitalism' as the best possible economic and political solution to global problems. During this period the US strengthened its position as the last world super-power, projecting itself as a benign empire in charge of the peace. In reality, this was marked by fiercely protecting the interests of the American capitalist class around the world at the expense of other countries, especially the Third World, which had to pay it tribute, largely through international institutions such as the International Monetary Fund and the World Bank (Harvey 2005).

I want to examine the ideology of Schindler's List in this context, not least because its director, Steven Spielberg, is both known for being an ardent supporter of Bill Clinton, and for epitomising the global domination of Hollywood cinema, marked by a smooth narrative, an individual character and conveying a message of hope, most importantly through the happy ending. Spielberg himself can be seen as an ultimate Hollywood capitalist, with numerous assets, including film studios and a personal fortune of about 3 billion dollars.

The Holocaust poses a challenge to the Hollywood narrative, as its main characters, the Jews, gassed in the gas chambers, it did not have a happy ending. How Spielberg coped with this challenge fills a large part of the literature devoted to this film (especially Loshitzky 1997). For the first half an hour or so of the film, Spielberg builds up a contrast between the worsening situation of Jews, and the improvement in the situation of the Germans, most importantly the eponymous character, following Germany's victory in the short war against Poland in 1939. While the Jews are deprived of their rights and their wealth, Germans or at least the German military/political class are getting richer and more powerful. Schindler receives a spacious and beautifully furnished apartment in Kraków, confiscated from a family of rich Jews.

Upon throwing himself on his new bed, he remarks that it cannot be better. At the same time the patriarch of a Jewish family, moved to a ghetto, moans when entering a dark and cramped flat which they have to share with another family that it cannot be worse for them. Spielberg thus offers us a succinct image of capitalist colonisation or what Marx describes as 'primitive accumulation' (or rather 'primary accumulation'): amassing wealth by taking it away from their owners. Such a scenario, as conveyed by David Harvey's term 'accumulation by dispossession' (Harvey 2005: 160-62), is realised also in contemporary times, practically in any country and region which was integrated into the capitalist order. But, of course, every version of capitalism is specific to its time and place, and the uniqueness of the Nazi version, as I already indicated, consisted of dispossession being coupled with a programme of annihilation of the dispossessed rather than utilising them economically. Or, more precisely, economic utilisation of Jews was a secondary objective to the goal of their extinction.

This is where Schindler enters the picture, so to speak. He is presented as an ideology-free businessman, who has no racial, ethnic, religious or indeed, any other prejudices. Any worker is good for Schindler as long as $\mathrm{s} /$ he produces a surplus value and the more he produces of it, the better. For this reason, as well as because he trusts the business talents of Jews more than his own, he decides to open a factory producing pots and pans employing Jews rather than Poles. He is allowed to pay less for Jewish work than for the Polish work and he does not need to pay the Jews for their work, only the state, a fact that does not bother him, or at least not initially. Soon he reaches a very high level of production and a high level of profit, facilitated by bribing the political and military establishment with shortage goods such as cognac, champagne and nylon stockings, purchased for him on the black market by Jews. He has to do this because, as one of his Nazi friends puts it, in the Reich using Jews economically is a treasonable act. This means, however, that the oppressed group have to pay their oppressors an extra price to be economically exploited, an idea which 
returned under a neoliberal regime, when the road to employment got longer and more twisted, with work being increasingly depicted as a privilege and act of charity on the part of businessmen. Schindler openly admits to his wife that the secret to his success is war. This is because war is a period of suspension of democratic rules (to the benefit of the upper classes) and the accelerated consumption of certain goods and, consequently, increased demand for them, which benefits their producers.

Although Jews do not receive any pay for their work, it is still very attractive for them to work for Schindler, as the alternative is staying the whole day in the ghetto, then the concentration camp and, finally, death. Thus what in other context would be represented as utter exploitation, since working in Schindler's factory required dealing with hot metal and hot chemicals, dangerous to workers' hands and their overall health, is here rendered as a great privilege. Even the fact that workers in Schindler's factory are exposed to accidents is presented as proof that working for him offers a semblance of normality, which they are denied outside his factory. Equally important is the fact that Schindler, unlike the SS men shown by Spielberg, and especially not like his business partner, Amos Goeth, who is the commander of the Paszów concentration camp, is not a sadist. Of course, this is because ordinary capitalism, unlike Nazism, is not sadistic - misery is only a by-product of capital accumulation, not its overall goal. And yet, both Goeth and Schindler divide Jews essentially according to the same criterion: being useful or useless as labourers. Both men's decisions have the power to grant life or sentence to death, as conveyed by the film's title: 'Schindler's List'. Yet, Goeth is presented as a murderer, Schindler as a saviour.

In this way Spielberg suggests that capitalism not only creates jobs, but save lives, unlike totalitarian ideologies which only destroy them. In the light of the lack of any other ideology on offer, as viewers of Spielberg's film, we also have to choose between the two ideologies. Capitalism, personified by the charismatic Schindler, wins over Nazism, personified by Goeth. Choosing capitalism over ideology-driven Nazism is helped by showing Schindler's moral maturation occurring in step with his development as a businessman and the behaviour of the Jews. The more profit Schindler makes, the more he is devoted to his workers and the more he is loved and respected by them, as if confirming the view that capitalism serves everybody because wealth trickles down. By the end of the film he behaves like a saint and he is treated like one both by his workers and the director who furnishes him with a high degree of pathos, embarrassing for some viewers. The Jews whom Spielberg shows come across as if devoid of any agency, passive and feminised, in this way conforming to a long tradition of representing Jews, exemplified by, among others, psychologist Bruno Bettelheim (Doneson 1997: 143). It appears that their only way to salvation is through Schindler; they give up on any other means of resistance, such as organising an escape or uprising, although in reality the Jews reacted in a very varied way to Nazi policies, including through engaging in underground activities. There was, as Judith Doneson notes, a Jewish fighting organisation, the ZOB, in the ghetto (ibid.: 145).

The idea that Jews are nothing without Schindler is clearly conveyed in a scene when Schindler rescues his diminutive manager, Itzhak Stern, from a train to the death camp and subsequently Stern apologises to Schindler for not having his documents when he was caught and in this way causing trouble for his boss. It appears that Stern and, by extension, all other Jews, see their role solely as wheels in Schindler's machine. They have no life outside it, no friends or families, although in reality Stern was married and his wife was with him throughout the war.

All Jews, as represented by Spielberg, unlike the prisoners in Munk's film, prefer to work than to fight and they take great pride in their work, irrespective of its purpose or context. It seems like it does it not matter for them whether they produce pots and pans, ammunition or a place where they will be exterminated what matters is that the work is done according to the highest standard. The most extreme example is a female engineer who supervises construction of the Paszów camp, 'who takes her work for the Nazis so seriously that she loses her life' (ibid.: 144).

The choice between 'Schindlerism' and 'Nazism' can be mapped to the way political choices were presented to the population in the dominant discourses since the 1980s: either capitalism or totalitarianism. Seeing Schindler as a predecessor of the neoliberal capitalists is augmented by furnishing him with certain features which we associate today with success in business, such as his heavy investment in his self-image and networking. Schindler begins his cinematic life as somebody who spends the little money he has on buying drinks for powerful Nazis frequenting Kraków restaurants and making sure that he is photographed with 
them. In his incessant PR exercise, Schindler bears resemblance to Hitler, unlike Goeth, who does not care about what people think about him. The image Schindler projects becomes a reality: a man taken for 'somebody important' becomes very important indeed. The capitalist is thus presented by Spielberg as somebody who can change the reality by the sheer power of his image, while the worker cannot change it by any means.

\section{Conclusions}

The films about Nazi concentration camps excellently illuminate the richness and complexity of the term 'work'. They point to the fact that work in the camp was 'labour', as defined by Marx, because it was alienated. This was a consequence of a desire of the Nazis and the Nazi system at large to exploit and oppress the prisoners, rather than to enrich them materially and spiritually. At the same time, the labour in the camp was varied, both in terms of the character of jobs performed, their hierarchy and awards and punishments granted for fulfilling them well and badly. Moreover, the system was very volatile, with promotions and demotions being granted fast and unexpectedly. Such a situation led to a deep longing on the part of the camp population to get a better job and a sense that their situation is in fact good when it happened. In a wider sense it shows that there are many stages and shades of alienated work. These variations act perfectly as a disciplining device, making those at the bottom of the human pile put up with their situation in the hope that they will move up, if they behave to their masters' satisfaction.

I also argue that life in a camp, as represented in reliable sources, especially first-hand testimonies and books based on them, can be used in advocating different work ideologies, most importantly state socialism and neoliberal idealism. I regard Schindler's List as a particularly successful attempt to use the story of camp prisoners to promote neoliberal capitalism. My hope is that a camp film will be made which will achieve similar success, yet advocating a different ideology - that of true socialism.

\section{Notes}

1. An example of this approach is offered by Omer Bartov in his seminal book, The 'Jew' in Cinema. His premise is that there should always be Jews in Holocaust films. Therefore when discussing Munk's Passenger he attempts to explain this absence (Bartov 2005: 177-78).

2. Especially useful was for me Franciszek Piper's Auschwitz Prisoner Labor (Piper 2002) and Eugen Kogon's The Theory and Practice of Hell (Kogon 2006).

3. This aspect of the camps is presented in Edgar Reitz's series Heimat (1984).

\section{Author Information}

Ewa MAZIERSKA is Professor of Contemporary Cinema at the Department of Humanities, University of Central Lancashire. Her publications include Masculinity in Polish, Czech and Slovak Cinema, Roman Polanski: The Cinema of a Cultural Traveller, Women in Polish Books (with Elżbieta Ostrowska), Crossing New Europe: The European Road Movie (with Laura Rascaroli), Dreams and Diaries: The Cinema of Nanni Moretti, and From Moscow to Madrid: Postmodern Cities, European Cinema. She also co-edited Relocating Britishness. 